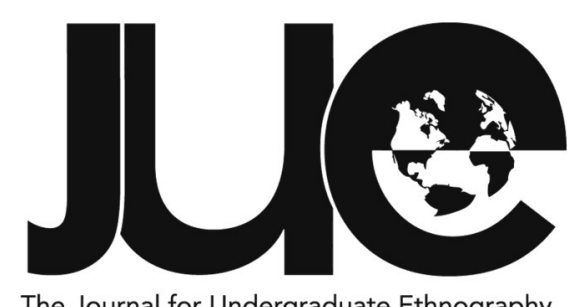

The Journal for Undergraduate Ethnography

\title{
Activists in Red Capes: Women's Use of The Handmaid's Tale to Fight for Reproductive Justice
}

\section{Madeline Yu Carrola}

Southwestern University, mycarrola@gmail.com

\section{ABSTRACT}

This paper examines women's use of the notable red and white handmaid costume from Margaret Atwood's The Handmaid's Tale at political demonstrations following the 2016 U.S. presidential election. Drawing on ten in-depth ethnographic interviews with women who participated in handmaid chapters, my study finds that interviewees began to wear the handmaid costume at political protests because they increasingly saw parallels between the United States and Gilead-the totalitarian society in Atwood's novel-as a result of the 2016 election. Participants viewed the costume as a feminist symbol that enabled them to increase awareness about women's issues, particularly related to reproductive justice. Additionally, interviewees saw the anonymity of the costume as a way to represent all women, especially those who were unable to participate in such protests. This study extends existing scholarship on social movements and women's activism in the United States by exploring women's reasons for involvement in this new form of protest and their use of dystopian popular culture as the basis of their performance activism.

Keywords: handmaids; performance activism; reproductive justice; 2016 presidential election; Margaret Atwood 
$\mathrm{n}$ the wake of the 2016 American presidential election, women's activism and political involvement surged (Kurtzleben 2018; Meyer and Tarrow 2018; Tatum and Manchester 2017). Women who participated in the January 2017 Women's March reported that they would continue engaging in activist work following the march, and 2018 saw a record number of women running for political office for the first time (Kurtzleben 2018; Spencer and Verdeja 2017). Additionally, newly formed activist groups and grassroots initiatives emerged as part of a larger anti-Trump resistance movement (Meyer and Tarrow 2018; Han and Oyakawa 2018).

Included in this global wave of resistance is a new form of protest: women who gather in public spaces and at demonstrations dressed as handmaids from Margaret Atwood's The Handmaid's Tale (see figure 1). These women are typically members of official handmaid chapters, found throughout the United States and in other countries, who organize around issues of women's reproductive rights and draw on the story's portrayal of a totalitarian society that oppresses women by restricting what they do with their bodies, whom they can love, and where they can live. In fact, handmaid protests have become so popular that they have been the subject of many mainstream news sources; for example, the BBC recently described the

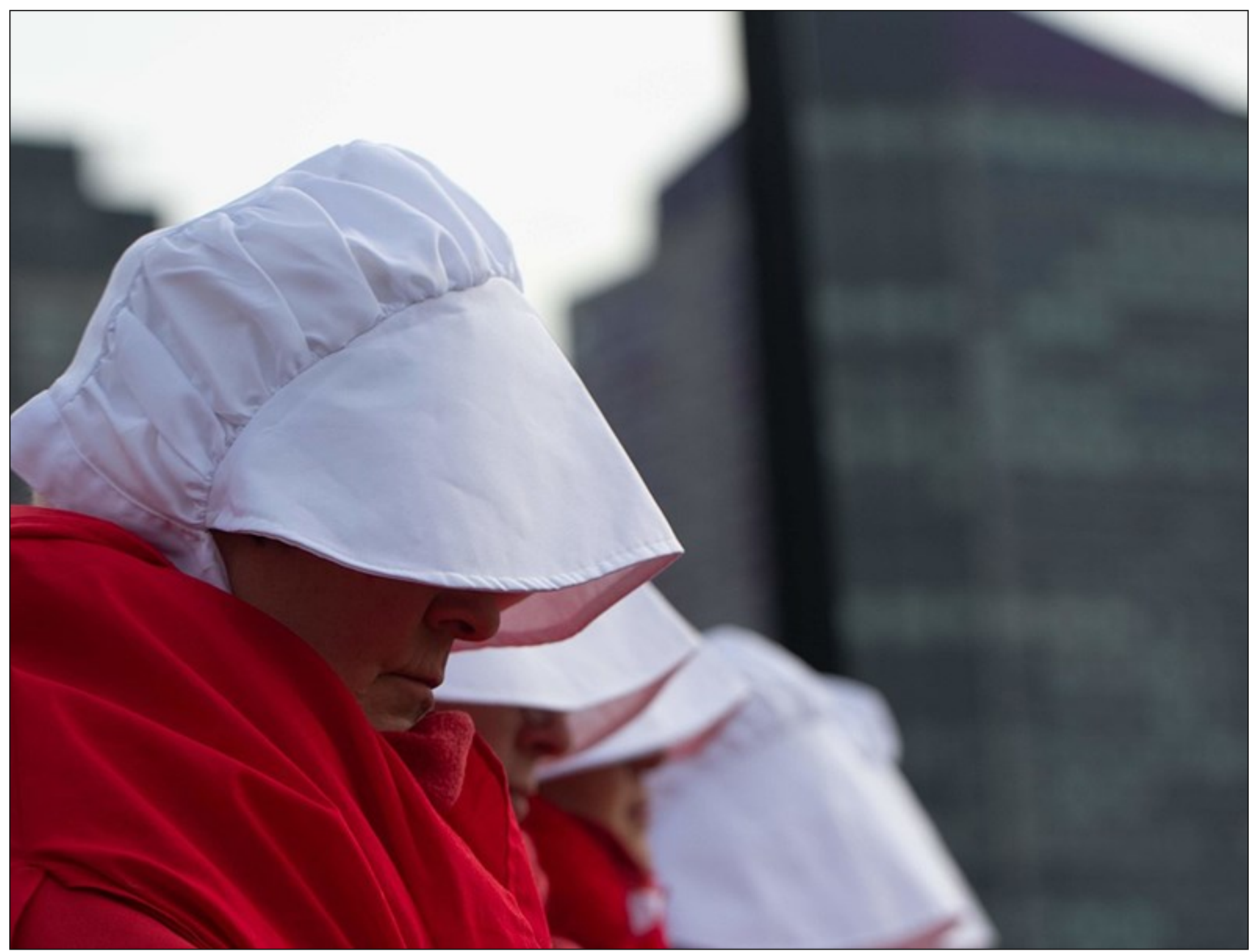

Figure 1. Handmaids Tale at the Boston Womens March, 2019. Kai Medina (Mk170101), CC BY-SA 4.0, via Wikimedia Commons. https://commons.wikimedia.org/wiki/File:Handmaids_Tale_at_the_Boston_Womens_March_2019.jpg 
costume as an "international protest symbol" (Alter 2018; Beaumont and Holpuch 2018; Bell 2018; Hauser 2017).

This paper investigates why these women have chosen to dress as handmaids as a form of political protest and the importance of the 2016 presidential election in their decision to mobilize. Because many of the activists who engage in this work are middle to upper middle class, white, middle-aged women, the current study also asks why this particular demographic group was attracted to a form of activism that relies so heavily on The Handmaid's Tale. In doing so, my ethnographic study builds on and extends existing scholarship on women's involvement in activism during the Trump era, performance activism as a form of political protest, the ways that activists use digital media to inform and enhance their work, and the potential for using feminist dystopia in women's political activism.

The next sections outline the theoretical framework, which draws on two bodies of literature: (1) cycles of protest and reasons for involvement and (2) performance activism. A discussion of the methodology follows. I then provide contextual information on The Handmaid's Tale before discussing the findings.

\section{Cycles of Protest and Reasons for Involvement}

Meyer and Tarrow (2018) consider the 2017 Women's March to be the beginning of what they term the "anti-Trump Resistance Movement" and the start of a new protest cycle. One characteristic of such a cycle is the development of new forms of protests (Tarrow 2018). For instance, scholars note that Indivisible, a national movement of grassroots activism that emerged as part of the anti-Trump resistance, used decentralized organizing tactics taken from the Tea Party, a fiscally conservative movement in the United States (Han and Oyakawa 2018; Indivisible, n.d.; Roth 2018). However, there has been less scholarly attention given to the dynamic ways that women's feminist activism has incorporated new forms of protest following the 2016 presidential election.
As new protest cycles emerge, different ways of becoming aware of and involved in activism can also develop (Gaby and Caren 2012; Jost et al. 2018; Roth 2018). For instance, the internet, and particularly Twitter and Facebook, have more recently become important ways that activists disseminate relevant and motivational information, attract potential recruits, and strengthen ties with like-minded members (Jost et al. 2018; Roth 2018). These patterns were found in the Occupy Wall Street movement, one of the first forms of protests to rely heavily on Facebook and Twitter to increase activist mobilization. In the Occupy protests, images shared on Facebook were particularly effective at gaining new activists and growing support for the movement (Gaby and Caren 2012) while Twitter hashtags and mentions were useful in message dissemination and engaging activists (Tremayne 2014). These strategies can help to establish connections with potential recruits and contribute to building activist networks via social media (Bastos, Mercea, and Charpentier 2015; Gibson and McAllister 2013). However, as previous scholars have argued, virtual ties alone do not replace the importance of inperson social ties for facilitating activist mobilization (Bastos, Mercea, and Charpentier 2015; Gibson and McAllister 2013).

Other factors also influence people's decision to participate in activism. For instance, a person is more likely to begin engaging in collective action when they see a potential for social impact, including the opportunity to influence policy change (Jasper 2011), the likelihood of building effective opposition (Hornsey et al. 2006), and the ability to impact the perceived views of the general public (Hornsey et al. 2006). In addition, emotions such as fear, moral shock, and anger can contribute to people's initial foray into activism (Beyerlein and Ryan 2018; Gould 2009; Jasper 2011; Kleres and Wettergren 2017). Although there is a growing amount of research on the role of emotions and activism more generally, there is little scholarly work to date on the ways that emotions may have motivated women to mobilize their political activist efforts in the wake of the 2016 presidential election. 


\section{Performance Activism}

In addition to the heightened role of social media and strong emotional responses to the 2016 presidential election in mobilizing individuals for collective action, performance emerged as a key component for handmaid activists. Drawing on fields such as anthropology, sociology, and performance studies, performance activism can be defined as

a particular kind of performance striving simultaneously to attract and hold attention and challenging the understandings and expectations of fellow protesters and the general public while, paradoxically, staying within the boundaries of these commonly held understandings and expectations [maximizing attention without alienating neutral observers]. (Kutz-Flamenbaum 2007, 91)

In other words, performance activism can include dramatic or ritualized performances, songs, poetry, and visual artwork that are intended as political actions, often to critique perceived inequities and injustices (Gould 2009; Heuvel 199l; Tate Modern 2020). Through these media, activists seek to disseminate their messages, encourage audience engagement, and educate others (Morandi 2020).

Activism in the United States has a notable history of performance, including groups such as ACT UP-an activist group formed in the 1980s to combat the AIDS epidemic and the dearth of adequate governmental response to the crisis-and various anti-war efforts (Gould 2009; Heuvel 1991; Kistenberg 1995; KutzFlamenbaum 2007; Meyer 2007; Wiegmink 2006). Humor, hyperbole, and staying in character are just a few strategies by which performance activism can challenge normative assumptions and communicate messages. For example, some of ACT UP's street performances incorporated jokes and targeted individuals through satire, while other demonstrations took on more grim or somber tones (Gould 2009). In addition, performance activism can incorporate aspects that are norm-embracing, norm-challenging, or both to disrupt normative ideas. For example, Raging Grannies, an antiwar group, has exhibited these strategies by playing on ageist and sexist assumptions about grandmothers (Kutz-Flamenbaum 2017). They practice norm-embracing strategies with oldfashioned clothing and their performance skits, while anger and sarcasm in their songs challenge norms (Kutz-Flamenbaum 2017).

Other performance activism strategies include performance structure. For example, some of Code Pink's informal, non-structured performance protests were more effective at encouraging audience participation than structured performances because of minimal wardrobe requirements and relatively accessible actions in which audience members were encouraged to participate. Structured performance practices that draw a more distinct boundary between audience and protester, like Missile Dick Chicks' character roles and detailed costumes that members make themselves, may have more potential in drawing attention to the specific messages or advocacy of the group, which are not always favorably received (Kutz-Flamenbaum 2007).

Moreover, recent forms of performance activism have gained global attention because of their association with particular symbols. For example, the Guy Fawkes mask, associated with the Occupy Wall Street movement, has become an international political icon and a symbol representing political dissent that continues to resonate beyond the movement (Kohns 2013). More recently, the pussyhat, popularized at the 2017 Women's March, was designed for aerial shots and cameras and continues to be associated with the women's movement (Larabee 2017). Despite marked differences between the Guy Fawkes mask and the pussyhat, these symbols share some combination of prolific media visibility and international use, which can contribute to effective political mobilization and recruiting new members (Gaby and Caren 2012).

The handmaid costume is another significant and recent example of the use of symbols in performance activism. Women have dressed as handmaids at state capitol buildings, the Supreme Court, and other public spaces across the globe to protest crisis pregnancy clinics, Brett Kavanaugh's confirmation, and other threats to women's reproductive rights, yet little scholarly research attends to this emerging 
protest strategy. This study addresses this gap by identifying reasons that some women have chosen to be involved in their respective handmaid chapters and their reflections on why they believe their performance activism is effective. Such a focus is particularly important given that women make up the majority of those involved in this activism, which uses potent symbols from dystopic popular fiction to draw attention to and resist dangerous policies exacerbated during the Trump Administration.

\section{Methodology: Interviewing Handmaid Activists}

This study relies on an analysis of ten semistructured, in-depth ethnographic interviews that I conducted between April and October 2018 (see table 1). For recruitment, I used convenience sampling and snowballing methods, specifically reaching out to various handmaid chapters' Facebook groups and posting my recruitment statement on those pages. Interviews ranged from thirty-nine minutes to one hour and thirty-six minutes, for an average of an hour and five minutes. All interviews were conducted in person or over the phone, and all identifying information was anonymized in the transcripts, including the names of interviewees' respective handmaid chapters. As part of the ethnographic interview, participants were asked questions about their upbringing, responses to the 2016 presidential election, involvement in handmaid activist groups, and their activist work more generally. Respondents were offered a copy of the transcript as compensation for their time and participation.

All interviewees are white women and ranged in age from 28 to 66 with an average age of 47 . The vast majority of participants are middle class and highly educated; most have a college degree and all have at least some college experience. Most respondents currently reside in the Southern United States, but two live in California and another resides in Maryland. Because the issues that chapters

Table 1: Respondent Demographics

\begin{tabular}{|c|c|c|c|c|c|c|}
\hline Respondent & $\begin{array}{l}\text { Handmaid } \\
\text { Group }\end{array}$ & $\begin{array}{l}\text { Level of Educa- } \\
\text { tion }\end{array}$ & Social Class & Marital Status & Age & Race \\
\hline Jane & California & Bachelor's & Upper Class & Married & $40 s$ & White \\
\hline Sarah & Texas & Master's & Middle Class & Married & $40 \mathrm{~s}$ & White \\
\hline SusieQ & Texas & Bachelor's & $\begin{array}{l}\text { Upper Middle } \\
\text { Class }\end{array}$ & Single & $40 \mathrm{~s}$ & White \\
\hline Helga & Texas & Some College & Middle Class & Married & $60 \mathrm{~s}$ & White \\
\hline SandeE & Texas & Bachelor's & Middle Class & Married & $50 \mathrm{~s}$ & White \\
\hline Carrie & California & Bachelor's & Middle Class & Single & $20 \mathrm{~s}$ & White \\
\hline Kristin & Texas & Post-Master's & $\begin{array}{l}\text { Middle/Upper } \\
\text { Middle Class }\end{array}$ & Married & $40 \mathrm{~s}$ & White \\
\hline Mary & Alabama & Some College & Working Class & Married & $40 \mathrm{~s}$ & White \\
\hline Noelle & Texas & Master's & $\begin{array}{l}\text { Middle/Upper } \\
\text { Middle Class }\end{array}$ & Married & $40 s$ & White \\
\hline Nicole & Maryland area & Bachelor's & $\begin{array}{l}\text { Middle/Upper } \\
\text { Middle Class }\end{array}$ & Partnered & $50 \mathrm{~s}$ & white \\
\hline
\end{tabular}


choose to organize around are influenced by the specific contexts of participants' lived environments, the regional diversity of my sample illuminates women's engagement in this type of performance activism across geographical contexts in the United States.

I relied on ethnographic interviews because they allow for a detailed and nuanced understanding of people's experiences and perceptions (Weiss 1995). Six interviews were conducted in person and the rest were done via phone. All interviews were digitally recorded and transcribed by the author. After analyzing each interview transcript multiple times, I identified two major themes: (1) a new cycle of protest and reasons for involvement and (2) performance activism. I coded the data with a trained undergraduate student coding partner; we had high intercoder reliability and when discrepancies in coding arose, we discussed them until we reached an agreement on the appropriate coding of the excerpts. I then selected representative interview excerpts to use in this paper as illustrations of the themes.

Overall, my positionality as a woman of color in my early twenties and self-identified feminist allowed me to cultivate trust and openness with respondents, as many had expressed a desire to engage younger women and women of color in their activist work. Also, my gender, race, and feminist positionality guided my interest in this topic and informed my analysis of the data. Below, I provide contextual information on The Handmaid's Tale before explaining my research findings.

\section{The Handmaid's Tale and Handmaid Groups}

Margaret Atwood's 1985 novel The Handmaid's Tale takes place in the fictitious country of Gilead at an unspecified time, a setting where fundamentalists and patriarchal governmental officials control every aspect of women's lives, including their reproductive choices. Some women are designated as handmaids who exist as surrogates for mothers who could not have children of their own in order to provide the country's male leaders and their wives with children. The novel is featured within the ranks of other classic dystopian literature, a genre that pulls on contemporary elements of society and casts an interplay of past, present, and imagined future to critique society and raise awareness around an issue. Following the election, many people began to identify frightening parallels between The Handmaid's Tale and the United States (Armstrong 2018; Morrison 2017).

Atwood's story has also been popularized by Hulu's widely successful adaptation of the novel, which began airing shortly after the election and has helped bring this twentieth century literature to a twenty-first century audience. Its modernized rendition resonates with today's political and cultural landscape as evidenced by parallels made between the story and the United States' current political climate concerning governmental efforts to restrict women's reproductive rights (Armstrong 2018; Morrison 2017). Another significant indicator of the story's resonance is the fascinating trend of women donning the handmaid costumes at various types of local, state, national, and international political protests (Beaumont and Holpuch 2018; Bell 2018; Bradley 2018; Hauser 2017).

Handmaid groups began emerging in the United States in January 2017. There is a substantial number of handmaid groups throughout the United States, and each U.S. state and the District of Columbia have participating chapters in the Handmaid Coalition (Handmaid Coalition, n.d.). Additionally, Argentina, Ireland, and England are just a few countries in which women have participated in handmaid protests (Bell 2018). Although each group maintains a level of autonomy, all are engaged in advancing reproductive rights and organizing around other social justice causes. In the United States, these include removing the statute of limitations for sexual violence, raising awareness of disproportionately higher maternal mortality rates among Black/African American women, abolishing Immigration and Customs Enforcement, and protesting Brett Kavanaugh's confirmation. 
"It was a moment of power:" Mobilizing Handmaid Groups for Performance Activism after 2016

I organize my findings by first discussing the motivations that catalyzed interviewees' activist mobilization and involvement in handmaid chapters following the 2016 presidential election, attending to the role of performance, social media, the striking imagery of the Hulu series, and perceived parallels between Gilead and the United States. In the section that follows, I explore participants' performance activism and strategies with a focus on imagery in their performance as handmaids and the strategies used to craft messages across audiences and continuously assert the handmaid figure's political significance.

\section{A New Cycle of Protest and Reasons for Involvement}

On November 9th, 2016, women across the United States awoke to the news that Donald Trump had won the presidential election. All ten respondents report having a visceral, negative reaction to the results. As Carrie, from California, explains: "Physically I was sick. I spent that whole morning throwing up. It was really emotional. And it wasn't just Trump. It was looking at so many other potential victories that we could have had and just seeing how that wasn't there. We're totally still in that." Carrie's response, like that of other interviewees, is notable given the role of emotions in activist mobilization and the political process at large (Jasper 2011) and speaks to the magnitude of fear and anxiety regarding women's rights in the United States following the presidential election. Additional reactions include those of Mary, from Alabama, who reports feeling "heartbroken...and utter disgust with my fellow human beings," and Noelle, in Texas, who "shut down for a few days." These comments illustrate the powerful emotional response that these women had to the election of Donald Trump. Their fear and anxiety, in turn, motivated them to reach out to local handmaid chapters and facilitated their involvement.

Contributing to their decision to join handmaid chapters, interviewees explained that one particularly powerful source of connection to the handmaids' imagery came from Hulu's The Handmaid's Tale series. In fact, eight women reported watching the series regularly. As explored in this subsection, viewers are presented with powerful visuals, narratives, characters, and storylines that dovetail with current political issues and may be more powerful and memorable than simply seeing text-based posts on Facebook or Twitter.

For five women, their participation in handmaid chapters was either their first activist involvement ever or the first time they had been engaged in political activism since their college years. SusieQ, from Texas, explains, "It [the election] woke me up again. I was on fire. I just thought, 'Oh my god I've been asleep at the wheel. Not that I could have personally changed anything for the last twenty years, but I was absolutely emboldened again...I thought, 'I'm not gonna go out like this. I'm gonna go down fighting, and I have to get involved."' SusieQ's comments highlight the connection between her reaction to the election and her intention to be involved. She is among three other interviewees who had not been active in social justice work since their college years. The results of the 2016 presidential election, then, proved to be a pivotal moment in these women's mobilization.

For the five other women, the 2016 presidential election altered their ongoing activist work. For example, Mary, an environmental activist in Alabama, says that the election, "inspired me to be more involved and you know fighting more on the social justice side and getting away from the environmental a little bit." Carrie, another prominent activist prior to the election in California, adds that her work "deepened in intensity." Both Carrie and another interviewee, Nicole, report having careers in creative, non-violent organizing, which helps to explain why not all participants began their activism as a result of the 2016 presidential election. Still, the election profoundly shaped their activism and heightened their interest in feminist activism in particular.

Notably, the women attributed their interest in becoming involved in feminist activism after Trump's election in part to a sense of 
differential privilege that they have as middle class white women. For example, Sarah, from Texas, reports, "We have a lot to fucking answer for...After the election, liberal white feminists like me got shook real hard because even though I'm not somebody with a lot of power or status, I am. I am a homeowner. I have a job. I have a Master's degree. My husband has those things too. We're raising our child in comfort." For many of these women, Trump's presidency was shocking and completely unexpected-an emotional response that prompted them to recognize their relative privilege. Such realizations led to a strong feeling of responsibility to engage in activism that they felt others, including some women of color and economically marginalized women, may not be able to participate in because of their differential access to time and other valuable resources.

Performance as handmaids was seen as an ideal way to use their privilege to engage in feminist activism and represent other, more vulnerable and marginalized women. As Helga, from Texas, explains, "I like to tell these women [who want to participate in activism but feel that they cannot] that they do participate, they are the ones in character with their heads down. I let them know it's okay to tell others that it's them under the cape. I represent all the women that want to be under the cape. That's very important to me." Helga's description of her performance activism as a handmaid suggests that participants view the costume, aided by the level of anonymity that it affords, as a collective symbol that represents all women whether they are actually dressed as a handmaid or not. This perception allows Helga and others to feel a part of something greater than themselves while simultaneously creating a space for other women who are unable to participate to imagine themselves there, too. In being able to engage in this type of feminist performance activism and represent other women, protesters perhaps re-inscribe their own sense of agency and add to their perceived impact, a component that clarifies the appeal of the handmaid costume and chapters (Hornsey et al. 2006).

Other reasons participants attributed their involvement in handmaid chapters to are social media, the striking imagery of the show, and perceived parallels between Gilead and the U.S. Prior studies indicate that most people join social movements because of the power of social ties (McAdam and Paulsen 1993). However, as studies on the Occupy Movement indicate (Gaby and Caren 2012; Tremayne 2014), social media platforms such as Twitter and Facebook are becoming more important in activist protests. For the participants in my study, six became involved as a result of reading posts on social media platforms and seeing news coverage about the handmaid protests. As Helga, from Texas, explains, "It was during Austin's annual SXSW festival. I saw some women on TV dressed as handmaids promoting the Hulu series. I thought, oh how I'd love to be a part of that. Soon after I heard about the NARAL [National Association for the Repeal of Abortion Laws] handmaid group and I actively pursued the group." Like Helga, other interviewees also revealed that the strong imagery of the protest groups on social media and the news prompted their decision to become involved (Gaby and Caren 2012).

One narrative from the series that participants reported particularly resonating with them following the 2016 presidential election is the extent to which male leaders in Gilead attempt to control women's freedoms and reproductive rights. They connect this narrative with what they see going on in the current political situation in the United States. SanDeE, from Texas, says, "I could see that [Gilead] was a potential outcome of everything that I've watched happen since I became aware of it [extremism]...I watched the rise of religious extremism and anti-abortion extremism in America, and the handmaids seemed like a logical conclusion." Recognizing the frightening parallels between Gilead and the perceived extremism in America today motivated SanDeE and others to become involved in a handmaid chapter as a form of protest. These groups also provided a unique way for the participants to engage in performance activism.

\section{Performing The Handmaid's Tale}

Performance activism includes dramatic or ritualized performances, visual artwork, and other artistic mediums intended to critique perceived inequities and injustices. I argue that 
the handmaid chapters in my study are a contemporary example of such activism; the women dress in the eye-catching handmaid costume, recreate the way characters in The Handmaid's Tale walk in two-by-two processionals, and coordinate their movements and behaviors with other handmaids in public settings. By performing elements of the story through these synchronized movements and the striking costume, interviewees achieve an attention-grabbing image that casts a comparison between Gilead and the United States to demonstrate their similarities. Chapters have used the handmaid costume and exhibited this performance in public spaces to oppose Roy Moore's candidacy in the 2018 Alabama senate race and Brett Kavanaugh's confirmation to the Supreme Court, to protest crisis pregnancy clinics, and to advocate for the removal of the statute of limitations for sexual assault and rape allegations in California. As explored below, I have categorized their performance activism strategies into two subthemes: imagery and crafting their message.

\section{Imagery}

Imagery is not only effective in attracting the women to participate in handmaid activism, but it also plays a meaningful part in their continued involvement. Drawing on the series and book, protesters wear ankle-length, red capes and white bonnets and often walk in pairs with their heads slightly bowed (see figure 2). Once settled in a location, they regularly choose to hold signs related to the political issue at hand, such as "abortion is normal" and "No Moore." Because the handmaid costume is so central to the story and has become a recognizable protest symbol, protesters are very intentional and deliberate about cultivating this image and using signs to clarify the purpose and message of each protest.

As many members of the California chapter work in media production, they rely on their professional skills and experience to stage and photograph protests designed for optimal camera exposure. Jane, from California, explains this process: "We produced it like a film, like what imagery do we want to see, what does the script look like, who are we casting in the red cloaks, what cameras do we want. We were very deliberate; we used our career experience to plan it." Jane's quote exemplifies the level of intentionality that went into producing short videos of the handmaid activists for social media purposes. Although video production was unique to the chapter in California, respondents in other states reported choreographing their entrances and having agreed upon behaviors for each demonstration. For instance, Sarah describes the choreography that went into protesting Senate Bill 8 at the Texas Capitol, a bill which bans fetal tissue donation, restricts late-term abortions, and requires fetal tissue to be cremated or buried: "On Monday, we decided we would have an action about it [SB8] and so she had us into two columns, and of course, the gallery is a square. She had us enter the doors, split off, go around, meet, pass each other, come back, and exit the gallery." Her description highlights the attention to detail that goes into coordinating protests. The formation into two columns, which mirrors the handmaid processions in the story, also demonstrates how members actively incorporate such characteristics into their protests.

Like the pussyhat, another protest symbol that emerged following the election, the handmaid costume is designed to be recognizable and a visually rich symbol for photographic purposes (Larabee 2017). The costume's vivid colors and departure from everyday clothing styles combined with choreographed movements make for an eyecatching image that has the ability to allude to a dystopian future. Both symbols rely on digital media for visibility and messaging purposes and support past research that predicts the greater use of digital media in social movements (Karpf 2018).

\section{Crafting their message}

Participants explained that they employ a variety of strategies to help ensure that their intended messages are being accurately conveyed to bystanders and journalists. These tactics include the costume, silence and chanting, use of protest signs, and designating a spokesperson. By far, the most crucial part of this performance is the costume. Sarah recalls this experience at the Texas Capitol: 


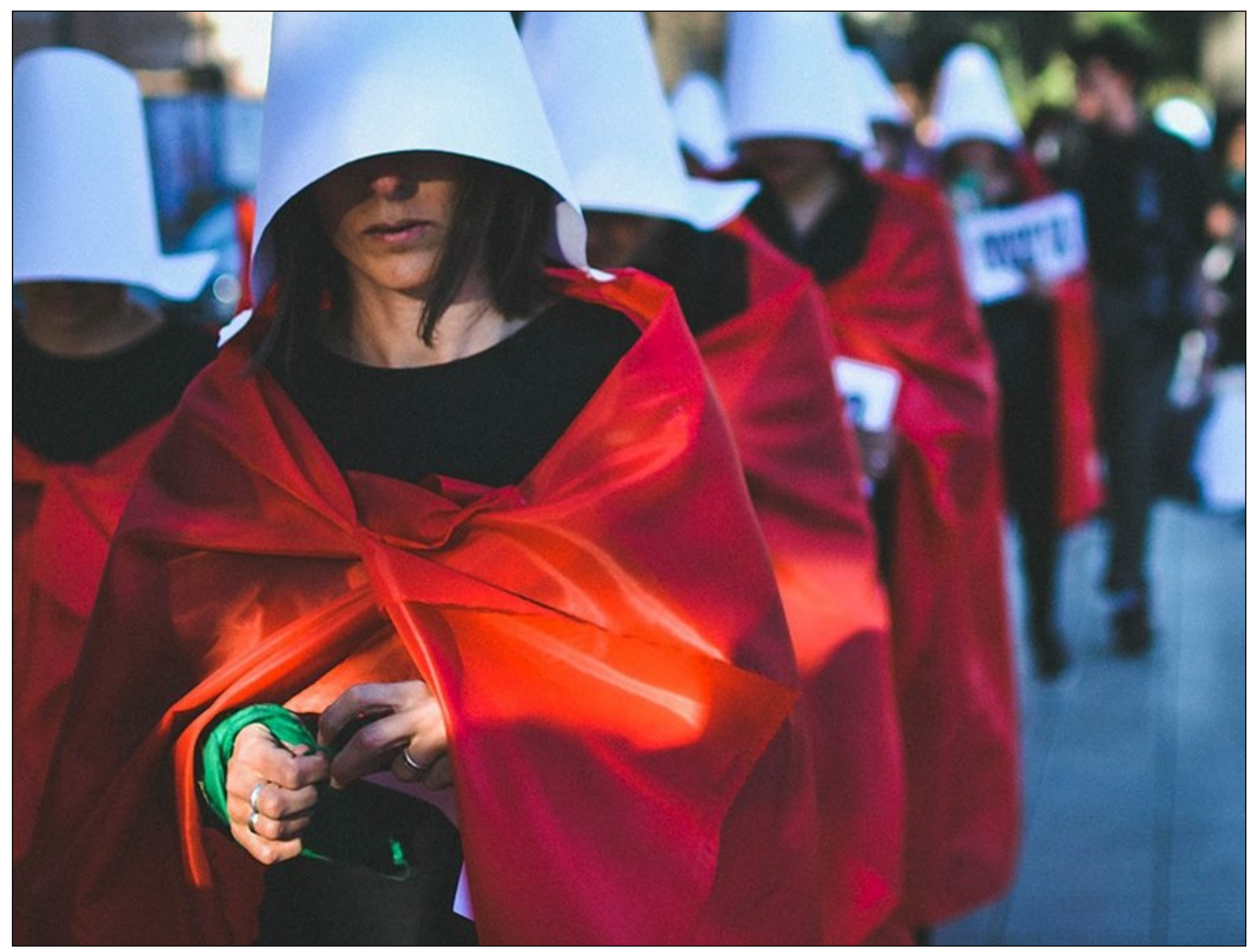

Figure 2. A Handmaid's Tale protest in Santa Fe, Argentina, to campaign for safe, legal, and free abortion. TitiNicola, CC BY-SA 4.0, via Wikimedia Commons. https://commons.wikimedia.org/wiki/File:Intervencion_The_Handmaid\%

27s_Tale_mala_junta_santa_fe_por_el_aborto_seguro_legal_y_gratuito_en_Argentina_09.jpg

We're walking at a brisk pace, well the capes, it's four yards of fabric. It billows out and you get bigger as you walk, and it's like grazing all these guys' shoulders as we go by...It poofs up like it's so cinematic you feel like such a badass...And it's enveloping these people who have ostensibly far greater power than I do as a lowly school teacher and definitely more wealth...But in that moment, you could just feel everybody go kinda still. It was a moment of power 'cause you don't think of getting those people's attention...It charges up the room.

Sarah's description of protesting Senate Bill 8 highlights the joint role of choreography and costume in these demonstrations and how they contribute to feelings of empowerment for participants. Other participants share Sarah's perspective. They reported that being in costume together in a political space is an especially politically empowering experience for them as women.

Similarly, women talk about the power of the costume to connect individual women together as members of a political community. Carrie, from California, says, “There's a sense of strength that comes from being there, not having to be there as yourself, but being there is literally a message that speaks beyond you as an individual and to a larger sense of camaraderie around something that's happening. The costume is like putting on a community in itself. It's taking on so much more than yourself." Carrie's comments indicate that the large bonnet and loose fabric of the gowns protect the activists' identities while both 
enabling the women to speak to something far greater than themselves and providing a sense of collective feminist identity.

Secondly, as part of this performance, protesters are often silent, which draws on the subservient nature of the handmaid character. This strategy also inhibits escalation with bystanders and affirms their non-violent stature, which helps prevent negative news coverage (Andrews and Caren 2010; Kistenberg 1995; Meyer 2007). As Kristin, from Texas, explains, "A lot of the silence is supposed to be reflecting the position that the handmaids in the show and the book have been put in, where they're being silenced... what it's supposed to be representing is that this is not a place... where we as America should be." Silence helps to further cast a symbolic parallel between Gilead and the United States-a parallel that creates a visceral experience for those protesting and one that protesters also hope to convey to bystanders.

Participants realize that their performance may not always effectively communicate their messages, especially if bystanders are unaware of the premise of The Handmaid's Tale. Therefore, some groups have, at times, incorporated the use of chants and signs while protesting. When asked about the reasons for chanting to protest Roy Moore's candidacy and Brett Kavanaugh's confirmation, Mary and Nicole explain that it had more to do with their position on the side of the road near traffic, making it a more practical decision. Mary adds that it was dark outside when they protested and therefore the costume was not as visible. Such decisions are significant because they highlight the intentionality of the handmaid performance and how respondents adapt to the specific context of their protest environment.

Protesters also regularly hold signs to ensure that their messaging is clear, which makes it less likely to be misconstrued by members of the media, the public, and bystanders. Signs specifically draw attention to the issue at hand without protesters having to engage directly with onlookers (see figure 3).

Handmaid chapters also typically designate a spokesperson who is not in costume and often already has a public identity to provide information and answer questions from journalists and bystanders. As SanDeE, from Texas, explains, "The handmaids show up and get press. The press love to stand there and take photos. The press wants to interview them...you have people like Sarah who answer questions." The spokesperson role gives reporters and bystanders a central figure to talk to who is well versed on the issues at hand and able to speak articulately on the matter. This role prevents those who are less informed on the issue from communicating the wrong message, helps protect the identities of those who do not wish to be public, and ensures that their message is being portrayed accurately. All of these protest decisions, including costumes, silence/chants, protest signs, and the use of a spokesperson during each protest suggest that handmaid protestors are particularly deliberate and thoughtful about the multiple dimensions of their group's protest performance and interactions with bystanders (Beaumont and Holpuch 2018; Bell 2018; Hauser 2017).

Despite similarities between the handmaid chapters and previous performance activist groups like ACT UP and Code Pink, the handmaids are distinctive because they are based on a culturally popular dystopian narrative. The handmaid costume as a protest symbol represents opportunities and challenges inherent in its allusions to popular culture and current political issues. Because of the costume's widespread recognition and place in popular culture, handmaid chapters appear to be better positioned than previous activist groups to reach greater and more varied audiences, a characteristic which may be particularly apt for recruiting new members (Gaby and Caren 2012). For instance, stories about handmaid protests have been tagged under "entertainment" as well as "news" sections, and they have been featured in online newspapers such as the Washington Post as well as popular press magazines like Vanity Fair (Bradley 2018; Joplin, Jewell, and Martin 2018).

However, it is the costume's very popularity and ability to blur the distinctiveness of "news" and "entertainment" that also contributes to one of its greatest challenges as a protest symbol. Regardless of the handmaid activists' 


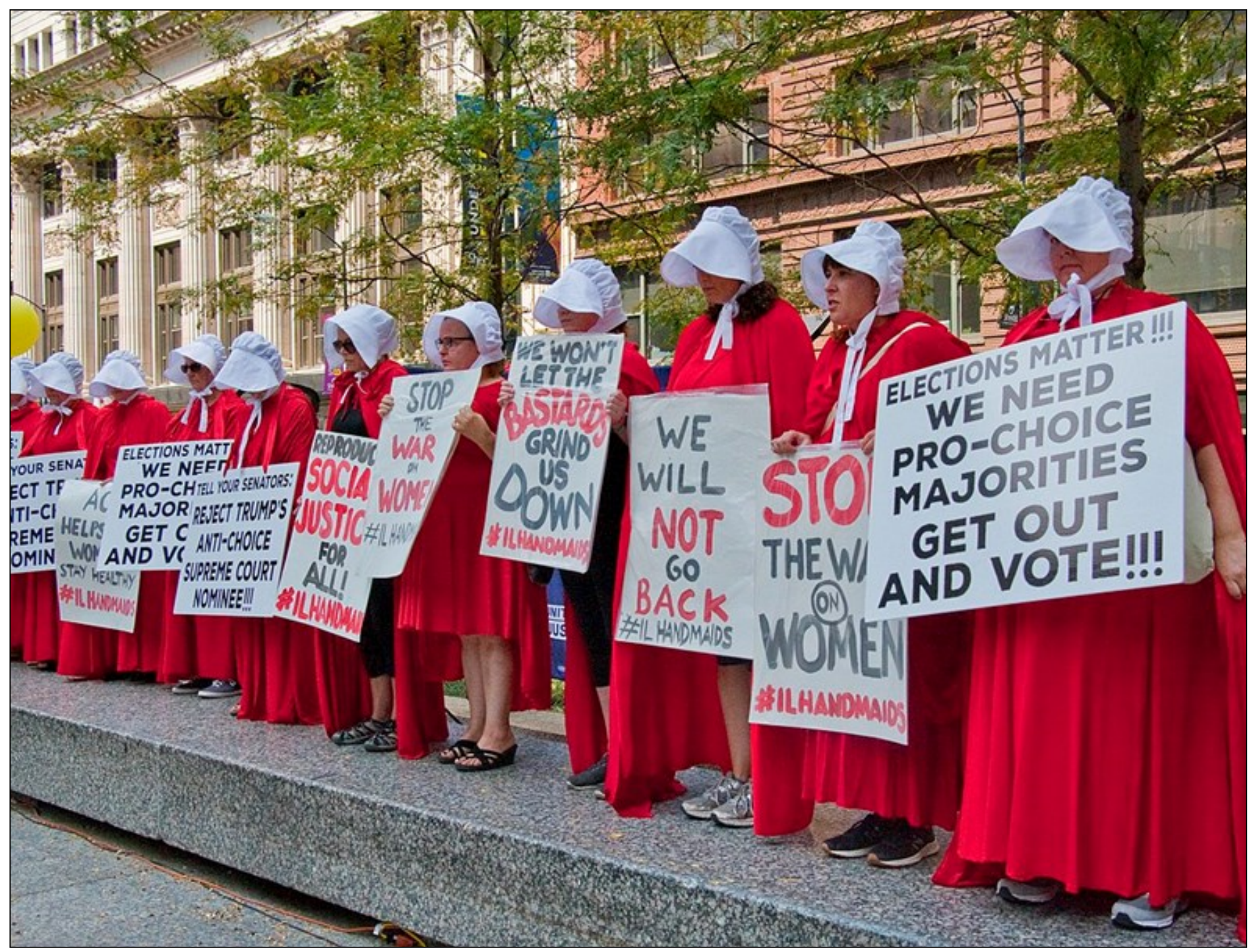

Figure 3. Illinois Handmaids Stop Brett Kavanaugh Rally, Downtown Chicago, Illinois, August 26, 2018. Charles Edward Miller from Chicago, United States, CC BY-SA 2.0, via Wikimedia Commons, https://commons.wikimedia.org/wiki/

File:Illinois_Handmaids_Stop_Brett_Kavanaugh_Rally_Downtown_Chicago_Illinois_8-26-18_3437_(42505508810).jpg

intentionality of their political symbols and performances, in the months leading up to Halloween in 2018, companies advertised the handmaid costume for the occasion (Vaglanos 2018; Wanshel 2018). Such advertisements are significant not only because they co-opt and depoliticize the costume and activist efforts of handmaid chapters, but also because they seem to undermine the feminist messages that handmaid chapters champion. Therefore, although popularity as a Halloween costume may lead to increased potential for the handmaid costume to receive greater recognition and receptivity as a political and popular culture icon, its leisurely or comedic use for a holiday like Halloween also poses risks to the costume's effectiveness as a protest symbol.
The above strategies serve as important ways in which these activists continue to assert the political meanings of the handmaid costume. By engaging in performance activism that draws on a storyline in popular culture, participants may potentially compete with media sources that elevate the entertainment aspects of The Handmaid's Tale and unwittingly or intentionally divert attention from the political relevance of the handmaid costume and dilute its significance. However, through the costume, choreography, and other political strategies, handmaid activists define and articulate the feminist connections between Atwood's story and the present political context. In doing so, handmaid activists continue to call for awareness and action 
around women's freedom and reproductive rights.

\section{Conclusion: From Fiction to Organizing a Feminist Future}

This study examines women's use of the handmaid costume from Margaret Atwood's The Handmaid's Tale for political protests and their reasons for doing so. Findings reveal that the 2016 presidential election was a pivotal moment for women, particularly middle to upper middle class, middle-aged, white women, to become involved in handmaid chapters. Women were drawn to these groups because of their knowledge of the storyline, their fear of a Trump presidency and what it meant for women's freedoms and reproductive rights, and news stories about women dressing as handmaids as a form of political protest. It was this combination that compelled them to find a handmaid chapter in their area often via social media.

Once involved in a handmaid group, participants choreographed their movements in various public spaces based on Atwood's dystopian storyline to draw attention to the perceived parallels between Gilead and the United States. In recreating the ritualistic processions and embodying the story's characters for protest, women also employed different strategies-like silence, chanting, and use of signs-to maximize the effectiveness of their messaging and to resist threats to women's reproductive rights.

Handmaids are different from other performance protest groups because of their creative and effective use of a popular culture reference to make broader political statements. My research shows some of the ways that The Handmaid's Tale as a figure in popular culture informs these protests groups and also how activists maximize this landscape by appropriating the costume and elements of the story. By occupying political news and entertainment spaces, interviewees may achieve greater exposure but must also continuously engage protest strategiesincluding the costume and use of signs-to assert the handmaid figure's political significance. In doing so, they are able to raise awareness about a number of issues focused on women's rights, including crisis pregnancy clinics, the statute of limitations for rape and sexual assault, and other issues that have been exacerbated within the context of Trump's presidency.

For these women, the book and Hulu series reflect and visualize their concerns about political issues in the United States today. The vivid handmaid image, coupled with activists' personal resonance with the storyline, enables them to be active in their own storytelling and be a part of something greater than themselves. Additionally, the costume's anonymizing effect allows participants to feel as though they are representing more marginalized or vulnerable women who may not have the same resources or opportunities to participate. In projecting the possibilities of a dystopian future, activists increase the story's relevance to those outside of academic circles, which allows for greater receptivity, identification with the narrative, and perceptions of empowerment-testifying to the role fiction can play in mobilizing individuals for collective action.

One limitation of my study is that I did not interview economically marginalized women or women of color to see if they feel represented by the handmaid activists as my participants intend, which offers a fruitful avenue for future research. Nevertheless, the election informed activists' sense of responsibility to advocate on others' behalf due to their privilege. Despite limitations, this study's findings are significant because they provide important insights into the ways that some women have been motivated to mobilize during the post-2016 presidential election era to engage in a unique and powerful form of feminist performance activism. Furthermore, it is important that we understand how women are actively navigating and resisting misogynistic policies and attitudes. With the rise of women-centered dystopia, The Handmaid's Tale's continued resonance almost thirty-five years after its inception and its use by women for political activism speaks to broader shifts in the way that women are defining and acting politically on their identities as feminists, activists, and agents of their own stories. 


\section{Acknowledgements}

I would like to thank Dr. Maria Lowe for her insight, guidance, time, and help with brainstorming and revision throughout this process. I am also very grateful for Samantha Pentecost's and Veronica Ciotti's assistance in the peer review and revision processes in addition to Dr. Reginald Byron for suggestions that strengthened my paper. I would also like to express appreciation to the respondents who shared their time and experiences with me. 


\section{References}

Alter, Alexandra. 2018. "How Feminist Dystopian Fiction is

Channeling Women's Anger and Anxiety." New York Times, October 8, 2018. https://www.nytimes.com/2018/10/08/books/ feminist-dystopian-fiction-margaret-atwood-women-metoo.html.

Andrews, Kenneth T., and Neal Caren. 2010. "Making the News: Movement Organizations, Media Attention, and the Public Agenda." American Sociological Association 75 (6): 841-866. https://doi.org/10.1177/0003122410386689.

Armstrong, Jennifer Keishin. 2018. "Why the Handmaid's Tale is so Relevant Today." BBC News, April 25, 2018. http://www.bbc.com/ culture/story/20180425-why-the-handmaids-tale-is-so-relevanttoday.

Bastos, Marco T., Dan Mercea, and Arthur Charpentier. 2015. "Tents, Tweets, and Events: The Interplay Between Ongoing Protests and Social Media." Journal of Communication 65 (2): 320-350. https:// doi.org/10.1111/jcom.12145.

Beaumont, Peter, and Amanda Holpuch. 2018. "How The Handmaid's Tale Dressed Protests Across the World." The Guardian, August 3, 2018. https://www.theguardian.com/world/2018/aug/03/how-the -handmaids-tale-dressed-protests-across-the-world.

Bell, Chris. 2018. "How the Handmaid Became an International Protest Symbol." BBC News, July 27, 2018. https://www.bbc.com/ news/blogs-trending-44965210.

Beyerlein, Kraig, and Peter Ryan. 2018. “Religious Resistance to Trump: Progressive Faith and the Women's March on Chicago." Sociology of Religion 79 (2): 196-219. https://doi.org/10.1093/ socrel/sry015.

Bradley, Laura. 2018. “Under Their Eye: The Rise of Handmaid's TaleInspired Protesters." Vanity Fair, October 9, 2018. https:// www.vanityfair.com/hollywood/photos/2018/10/handmaids-taleprotests-kavanaugh-healthcare-womens-march.

Gaby, Sarah, and Neal Caren. 2012. “Occupy Online: How Cute Old Men and Malcolm X Recruited 400,000 US Users to OWS on Facebook." Social Movement Studies 11 (3-4): 367-374. https:// doi.org/10.1080/14742837.2012.708858. 
Gibson, Rachel K., and Ian McAllister. 2013. "Online Social Ties and Political Engagement." Journal of Information Technology \& Politics 10 (1): 21-34.

https: doi.org/10.1080/19331681.2012.712461.

Gould, Deborah B. 2009. Moving Politics. Chicago: The University of Chicago Press.

Handmaid Coalition. n.d. "Join Us." Handmaid Coalition. Accessed November 1, 2018. https://handmaidcoalition.org/join.

Han, Hahrie, and Michelle Oyakawa. 2018. "Constituency and Leadership in the Evolution of Resistance Organizations." In The Resistance: The Dawn of the Anti-Trump Opposition Movement, edited by David S. Meyer and Sidney Tarrow, 230-245. New York: Oxford University Press.

Hauser, Christine. 2017. "A Handmaid's Tale of Protest." New York Times, June 30, 2017. https://www.nytimes.com/2017/06/30/us/ handmaids-protests-abortion.html.

Heuvel, Michael Vanden. 1991. Performing Drama/Dramatizing Performance: Alternative Theater and the Dramatic Text. Ann Arbor: University of Michigan Press.

Hornsey, Matthew J., Leda Blackwood, Winnifred Louis, Kelly Fielding, Ken Mavor, Thomas Morton, Anne O'Brien, Karl-Erik Paasonen, Joanne Smith, and Katherine M. White. 2006. “Why Do People Engage in Collective Action? Revisiting the Role of Perceived Effectiveness." Journal of Applied Social Psychology 36 (7): 17011722. https://doi.org/10.1111/j.0021-9029.2006.00077.x.

Indivisible. n.d. "About." Indivisible. Accessed December 15, 2020. https://indivisible.org/about.

Jasper, James M. 2011. "Emotions and Social Movements: Twenty Years of Theory and Research." Annual Review of Sociology 37: 285-303. https://doi.org/10.1146/annurev-soc-081309-150015.

Joplin, Ashleigh, Hannah Jewell, and Patrick Martin. 2018. "Hollywood Handmaids Protest Outside Golden Globes." Washington Post, January 7, 2018. https://www.washingtonpost.com/video/ entertainment /hollywood-handmaids-protest-outside-goldenglobes/2018/01/07/2f2925c2-f423-11e7-9af7a50bc3300042_video.html?utm_term=.72321a44ce05. 
Jost, John T., Pablo Barber, Richard Bonneau, Melanie Langer, Megan Metzger, Jonathan Nagler, Joanna Sterling, and Joshua A. Tucker. 2018. "How Social Media Facilitates Political Protest: Information, Motivation, and Social Networks." Advances in Political Psychology39 (1): 85-118. https://doi.org/10.1111/pops.12478.

Karpf, David. 2018. "The Many Faces of Resistance Media." In The Resistance: The Dawn of the Anti-Trump Opposition Movement, edited by David S. Meyer and Sidney Tarrow, 143-161. New York: Oxford University Press.

Kistenberg, Cindy J. 1995. AIDS, Social Change, and Theater: Performance as Protest. New York: Garland Publishing Inc.

Kleres, Jochen, and Asa Wettergren. 2017. "Fear, Hope, Anger, and Guilt in Climate Activism." Social Movement Studies 16 (5): 507519.

Kohns, Oliver. 2013. "Guy Fawkes in the 21st Century. A Contribution to the Political Iconography of Revolt." Image and Narrative 14 (1): 89-103.

Kurtzleben, Danielle. 2018. "Is The Record Number Of Women Candidates A 2018 Blip- Or A Lasting Trend?" NPR, September 25, 2018. https://www.npr.org/2018/09/25/651085628/is-the-recordnumber-of-women-candidates-a-2018-blip-or-a-lasting-trend.

Kutz-Flamenbaum, Rachel V. 2007. “Code Pink, Raging Grannies, and the Missile Dick Chicks: Feminist Performance Activism in the Contemporary Anti-War Movement." NWSA Journa/ 19 (1): 89-105. https://www.jstor.org/stable/4317232.

Larabee, Ann. 2017. “Editorial: Pussy Hats as Social Movement Symbols." The Journal of Popular Culture 50 (2): 215-217. https:// doi.org/10.1111/jpcu.12547.

McAdam, Doug, and Ronnelle Paulsen. 1993. "Specifying the Relationship Between Social Ties and Activism." American Journal of Sociology 99 (3): 640-667. https://www.jstor.org/ stable/2781286.

Meyer, David S. 2007. The Politics of Protest: Social Movements in America. New York, NY: Oxford University Press.

Meyer, David S., and Sidney Tarrow. 2018. "Introduction." In The Resistance: The Dawn of the Anti-Trump Opposition Movement, edited by David S. Meyer and Sidney Tarrow, 1-26. New York, NY: Oxford University Press. 
Morandi, Jessica. 2020. "Performance Art as an Activist Tool." Harvard Political Review, March 7, 2020. http://harvardpolitics.com/ culture/performance-art-activism/.

Morrison, Patt. 2017. "Margaret Atwood on Why 'The Handmaid's Tale' is More Relevant Now Than Ever." Los Angeles Times, April 19, 2017. https://www.latimes.com/opinion/op-ed/la-ol-pattmorrison-margaret-atwood-hulu-handmaiden-20170419htmlstory.html.

Roth, Benita. 2018. "Learning From the Tea Party: The US Indivisible Movement as Countermovement in the Era of Trump." Sociological Research Online 23 (2): 539-546. https:// doi.org/10.1177/1360780418764733.

Spencer, Bettina, and Ernesto Verdeja. 2017. "Nevertheless, She Persisted: Mobilization after the Women's March." Interdisciplinary Perspectives on Equality and Diversity Special Issue: Women's March \& Trump 3 (2): 1-17.

Tarrow, Sidney. 2018. "Rhythms of Resistance: The Anti-Trumpian Movement in a Cycle of Contention." In The Resistance: The Dawn of the Anti-Trump Opposition Movement, edited by David S. Meyer and Sidney Tarrow, 187-206. New York: Oxford University Press.

Tate Modern. n.d. "Performance Art: The Angry Space, Politics and Activism." Tate Modern. Accessed December 15, 2020. https:// www.tate.org.uk/art/art-terms/p/performance-art/angry-spacepolitics-and-activism.

Tatum, Sophie, and Julia Manchester. 2017. "What's Next for Women Spurred to Activism by Trump's Election?" CNN, April 30, 2017. https://www.cnn.com/2017/04/30/politics/women-trump-100days/index.html.

Tremayne, Mark. 2014. "Anatomy of Protest in the Digital Era: A Network Analysis of Twitter and Occupy Wall Street." Social Movement Studies 13 (1): 110-126.https:// doi.org/10.1080/14742837.2013.830969.

Vaglanos, Alanna. 2018. “Yes, Yandy Really Made A 'Sexy' 'Handmaid's Tale' Halloween Costume." Huffington Post, September 21, 2018. https://www.huffpost.com/entry/yes-yandy-really-made-a-sexyhandmaids-tale-halloweencostume_n_5ba4f1afe4b0181540dc4c08. 
Wanshel, Elyse. 2018. “Now A Company Is Using 'The Handmaid's Tale' To Sell Lingerie." Huffington Post, April 17, 2018.https:// www.huffingtonpost.com/entry/lingerie-lunya-the-handmaidstale_us_5ad4f239e4b016a07egf67f1.

Weiss, Robert Stuart. 1995. Learning From Strangers: The Art and Method of Qualitative Interview Studies. New York: Free Press.

Wiegmink, Pia. 2006. “Performing Resistance: Contemporary American Performance Activism." COPAS: Current Objectives of Postgraduate American Studies 7.http://dx.doi.org/10.5283/ copas.86.

Wikimedia Commons contributors, "File:Handmaids Tale at the Boston Womens March 2019.jpg," Wikimedia Commons, the free media repository, https://commons.wikimedia.org/w/index.php? title=File:Handmaids_Tale_at_the_Boston_Womens_March_2019.j pg\&oldid=432359599 (accessed August 31, 2020).

Wikimedia Commons contributors, "File:Illinois Handmaids Stop Brett Kavanaugh Rally Downtown Chicago Illinois 8-26-18 3437 (42505508810).jpg," Wikimedia Commons, the free media repository, https://commons.wikimedia.org/w/index.php? title=File:Illinois_Handmaids_Stop_Brett_Kavanaugh_Rally_Downt own_Chicago_Illinois_8-26-18_3437 (42505508810).jpg\&oldid=419408575 (accessed August 31, 2020).

Wikimedia Commons contributors, "File:Intervencion The Handmaid's Tale Mala Junta Santa Fe por El Aborto Seguro Legal y Gratuito En Argentina 09.jpg," Wikimedia Commons, the free media repository, https://commons.wikimedia.org/w/index.php? title=File:Intervencion_The_Handmaid\% 27s_Tale_mala_junta_santa_fe_por_el_aborto_seguro_legal_y_grat uito_en_Argentina_09.jpg\&oldid=313792177 (accessed August 31, 2020). 